\title{
The association between partnership financial integration and risky audit client portfolios
}

\author{
July 312006 David Hay*, Rachel Baskerville** and Travis Hui Qiu** \\ University of Auckland Business School, New Zealand \\ ** Victoria University of Wellington, New Zealand
}

\begin{abstract}
Address for correspondence: Associate Professor David Hay, Department of Accounting and Finance, University of Auckland Business School, Private Bag 92019, Auckland, New Zealand. d.hay@auckland.ac.nz
\end{abstract}

Submitted to: Auditing: A Journal of Practice and TheoryPlease do not cite without full attribution

SUMMARYThis study examines whether profit-sharing arrangements within accounting firms are associated with the riskiness of their client portfolios. Our results use unique data about the profit-sharing arrangements of the Big 8 firms during the period 1985-1994. We investigate whether there is a correlation between profit-sharing and risky clients. Firms consist of the financially-integrated firms, i.e. those that share their profits across a large pool of partners across the country, and the financially-independent firms, which share their profits in a small pool on a local office basis. The large-pool firms provide more incentive for partners to cooperate to audit high-risk clients than the small-pool firms. Our results show that the large-pool firms are associated with riskier client portfolios; this is indicated by a higher proportion of fees from clients that later suffer from bankruptcies. In contrast, a smaller proportion of the clients of the small-pool firms go bankrupt. Tests using alternative measures of client risk confirm this result. 


\section{INTRODUCTION}

This paper adds to our understanding of audit firms by investigating the partner profit-sharing schemes and client portfolio characteristics of Big 8 firms in New Zealand from 1985 to 1994 . Under different profit-sharing arrangements, partners have different incentives in dealing with clients, peer partners and subordinate staff, which can potentially influence firms' client selection and continuance decisions (Burrows and Black 1998; Liu and Simunic 2005). We find that partnerships which used profit-sharing on a national basis as a means of sharing risk had more risky portfolios of audit clients. This is consistent with the suggestion by Liu and Simunic (2005) that variations in profit sharing rules among firms are an efficient response to the market so that large pool firms can specialize in complex or high-risk clients and small pool firms can specialize in simple or low-risk clients.

\section{LITERATURE REVIEW}

Several recent studies show that major audit firms manage their portfolio of clients according to client risk. Krishnan and Krishnan (1997) show evidence consistent with the proposition that audit firms adjust their portfolios by withdrawing from high-risk client engagements. Jones and Raghunandan (1998) found that over a period of increasing litigation from 1987 to 1994, there was a significant reduction in the likelihood of Big 6 audit firms having clients that were relatively risky, risky clients being defined as those in financial distress or in high-technology industries. The law then changed to reduce auditor liability (with the passage of the Private Securities Litigation Reform Act of 1995). Francis and Krishnan (2002) reported that the Big 6 firms then relaxed their risk management policies, accepting riskier clients and adopting less conservative audit reporting. Choi et al. (2004) found that although Big 6 firms increased their market share during a period of increasing liability, they 
did not increase their share of the financially riskier clients. Risk was measured using financial distress measures including Altman's Z-score and financial ratios. These studies, and other investigations into the issue, are important because "assessing whether auditors manage risk at the client portfolio level potentially provides additional insights into how client risk factors influence auditor behavior" (DeFond 2004). However, none of these papers are able to distinguish among the client choices made by the different Big 8 firms, which have different profit-sharing pools and therefore different incentives concerning risk.

Although auditor liability in New Zealand is not exactly the same as in the US settings examined in previous studies, litigation risk is important in New Zealand and influences auditor behavior. Auditors are liable when their negligence results in loss to a party to whom a duty of care is owed (Hay and Davis, 2004). New Zealand has been shown to have a broader scope of liability than other Commonwealth countries (Pacini et al. 2002). Auditors are seen as the 'deep pockets' defendant in New Zealand (Fisher 2000) and, as a result, can face costly litigation even when a case does not have merit. Auditor liability risk is not completely covered by insurance in New Zealand, like other countries. Audit firms have high premiums, a high 'excess' (deductible) and an element of self-insurance (McManus, 1993).

There are a number of papers demonstrating that there are differences among accounting firms in their profit sharing pools and that these make a difference to firm behavior. Burrows and Black (1998) examine the profit sharing schemes used by the Melbourne office of the Big 6 firms in 1995. They found a trend towards large pools, and that all of the firms except KPMG used large pools. Liu and Simunic (2005) suggest that differences in the pools used by firms exist because different firms choose different profit-sharing rules to specialize in different types of clients. The 
audit of a large international company probably requires more partner cooperation than the audit of a small local company, and the extent of industry-specific knowledge needed may also be a factor. Liu and Simunic (2005) noted that KPMG was a smallpool firm, specializing in small and simple companies, while Arthur Andersen was a large-pool firm specializing in large and complex companies. Although Liu and Simunic's (2005) model suggests that both large-pool and small-pool firms exist because variations among firms are efficient, Burrows and Black (1998) argue that there is a continuing trend towards large pools.. The contrast between these two views in the literature also supports the need for further research.

There is also some evidence consistent with profit sharing influencing partner objectivity. Trompeter (1994) and Carcello et al. (2000) suggested that partners who receive a share of profits based on local office performance (i.e., in 'small-pool' firms) may have their objectivity impaired in some circumstances. This effect is less likely to apply to those sharing more broadly in 'large-pool' firms. Trompeter (1994) found that partners in small-pool firms were less likely to require clients to make adjustments to the financial statements. Carcello et al. (2000) find no direct association between firm pool and auditors' decisions, but that partners in small-pool firms are more sensitive to client size when making going concern decisions.

Holmes and Zimmer (1998) found that profit-sharing on a local or national basis is determined by the ability to use teamwork efficiently across locations. They show that accounting firms sharing profits on a local basis are likely to share them equally, while partnerships sharing on a national or international basis are likely to have performance-based profit sharing rules.

There are several reasons why large-pool firms can take on riskier clients. The audit of high-risk clients requires more partner cooperation than the audit of a low- 
risk client, and partners from other offices have more to gain by cooperating if profitsharing is based on larger pools. In addition, partners are sharing the risk with a wider group, and can be less risk averse as far as any specific client is concerned.

The firms structuring themselves in these ways means that incentive alignment is likely to be more appropriate, as each firm can have its partner compensation arrangements in line with the optimal criteria for client acceptance or rejection. Francis $(2004,362)$ expresses concern that a trend towards a more performance-based incentive approach for audit firm partners leads to partners being rewarded personally for risk-seeking behavior, while the entire firm bears the risk and liability. If more firms are moving to large-pool structures, then that would be consistent with the firms taking greater risk.

\section{RESEARCH METHODOLOGY AND DATA SOURCES}

In this study, we are able to examine audit firm portfolios much more directly than previous studies such as Jones and Raghunandan (1998), Francis and Krishnan (2001) and Choi et al. (2004) because we have the advantage that we can distinguish among the Big 8 firms according to their profit-sharing pool. Analysis of the profitsharing pools in Big 8 firms was an outcome of an oral history project conducted by one of the authors in 2002 (Baskerville and Beechey 2004). Partners who had retired from Big 8 firms were interviewed using oral history protocol. The interview transcripts were approved by the former partners and placed on the public record at the National Oral History Archives of New Zealand. Table 1 shows the profit-sharing schemes used by each firm. 


\section{[Insert Table 1 about here]}

We use subsequent client bankruptcy as the measure of financial distress. Thus the riskiness of a client portfolio is directly observed, albeit ex post. In addition, we test whether profit sharing in a large pool is associated with risky clients using ex ante measures of risky industries and financial ratios similar to those in previous studies. The hypothesis to be tested is that the proportion of risky clients in the fee portfolio is higher for the firms sharing profits among a large pool of several offices, when compared with those partnerships that operated in small pools sharing profits locally without national financial integration.

Audit fees and other financial report data were obtained from the University of Otago financial report database with extensive corrections and additions. Classifications of client company loss are identified from the Stock Exchange Annual Report from 1985 to 1989, Stock Exchange Review and Stock Exchange Review Supplement published by the New Zealand Stock Exchange from 1990 to 1994. These documents report the reasons for de-listing for those companies removed from the list. For companies de-listed because of breach of the listing requirement, a further investigation was conducted by searching online databases including Companies Office database, News Index, and Newztext, newspapers and annual reports.

\section{RESULTS}

We classified the audit fees for each firm's portfolio of clients in each of the years from 1985 to 1994 into clients that subsequently went into bankruptcy and those that did not. We examined the subsequent history of these clients until 2002. The percentage of fees for each firm from clients who were subsequently bankrupt in the next five years is shown in Table 2. Prediction of bankruptcy of any individual 
company in any year is a difficult task (as shown by studies of auditors' going concern reports) but prediction is less difficult over a longer period, and over a larger sample. An audit partner or firm may have difficulty in assessing which particular client will become bankrupt in any particular period. However, a firm which has a higher proportion of bankrupt clients over a sustained period has evidently been accepting higher risks. We use a five-year time horizon and the firm's portfolio of listed company clients, with further examination of the entire period until 2002, and sensitivity tests examining two year and one year periods.

The results show that firms that had a national income-sharing structure generally had higher-risk portfolios. In particular, the national-income sharing firm Coopers \& Lybrand had a much higher share of fees in the 1980s from clients that were to go bankrupt. In the 1990s, Australasian-income sharing Price Waterhouse took over the position as having the highest percentage of fees from clients that later went bankrupt. (Price Waterhouse in this period did not have a large number of listed clients, concentrating instead on subsidiaries of multinational clients, and as a result of the small numbers, its figures show some extreme variations.) National-income sharing Touche Ross also had a consistently high share of fees from clients that were later to fail. In contrast, local-income sharing Ernst \& Whinney and Peat Marwick (later KPMG) consistently had a low percentage of their fees coming from clients that later failed. As a sensitivity test, we repeated this analysis examining client bankruptcies over the entire period of the study (until 2002). The results are very similar.

\section{[Insert Table 2 about here]}

Table 3 summarizes the evidence using audit fee data combined according to the profit-sharing pools used by the firms, and broken down according to which clients subsequently went bankrupt in the next five years. The large-pool firms received 9.38 
percent of their fees from risky clients, compared to 2.82 percent for the small-pool firms. These statistics are consistent with the hypothesis that the proportion of the fee portfolio that was subsequently bankrupt is higher for the firms sharing profits among several offices in every year, and in many cases it is substantially higher. This is especially the case in the late 1980s. The results are consistent across the relatively long period. As a sensitivity test, we also conducted this analysis using an alternative definition of risky clients as those which went bankrupt over the entire period of the data until 2002. These results are very similar.

\section{[Insert Table 3 about here]}

Tests of the significance of the differences in client portfolios are reported in Table 4. The frequency of client failure was higher for large-pool firms, whether measured by failure within five years or failure by 2002. These differences are significant using chi-squared tests. The mean percentage of risky clients in the fee portfolio is also higher for the large-pool firms. Taking the mean percentage of risky clients in each year gives a mean failure rate 11.06 percent for all of the large-pool firms and 3.26 percent for the small-pool firms (11.63 percent and 3.46 percent when using failure within the entire period). These differences are significant at less than 1 percent. ${ }^{[2]}$ We also report the results using bankruptcy within two years as the measure of risk. These results are (just) not significant, but in the expected direction. It is more difficult to predict bankruptcy over a shorter period, but portfolios of riskier clients can be identified over longer periods. The means in Table 4 are computed audit firm by audit firm, and differ slightly from the means of all clients reported in Table 3.

\footnotetext{
${ }^{[2]}$ As a sensitivity test to ensure that these results are not driven by a single firm, we eliminated each firm in turn from the analysis. The significance levels remain approximately the same.
} 


\section{[Insert Table 4 about here]}

Previous studies have examined other measures of risky clients including financial ratios. Table 5 reports tests of whether the client portfolios were different in risk using ex ante measures such as debt and liquidity. We use measures similar to those reported in Choi et al. (2004). These are Altman's Z-score, Zmijewski's distress score, the current ratio, the quick ratio, net profit margin (as a percentage of sales), return on assets (earnings before interest and tax to total assets), receivables to assets, sales to assets and total liabilities to assets.

\section{[Insert Table 5 about here]}

The Altman's Z-score and Zmijewski's distress score measure financial distress by applying weights to various other ratios. The remaining ratios are individual measures of risk or liquidity. The results show that the large-pool clients are more risky using Altman's Z-score, and that this is significant. We also calculate the Zscore weighted by audit fees, which gives a more relevant measure of the risk in a portfolio of clients. The difference is also in the predicted direction and significant. Using Zmijewski's distress score, the large-pool firms also have more risky clients; this difference is not significant for the simple average of distress scores, but is significant when weighted for the level of audit fees. Liabilities to assets are also significantly higher for the large-pool firms. Sales to assets are also higher - this may be because the risky clients of the large-pool firms generate more of their revenue from the types of assets that are not found on the balance sheet. The other ratios do not show significant differences, probably due to the limitations inherent in using a single measure to assess overall risk. 
The Z-score and Zmijewski distress score measures were not specifically designed for New Zealand companies and thus have some limitations. However, they allow us to conduct this sensitivity test, and we are not relying on the specific number produced by these measures, but simply on the overall level of financial distress indicated by combining these ratios. Subsequent failure by clients is a more comprehensive and relevant measure of the riskiness of a client portfolio, however.

It might be suggested that other factors, including client size or complexity could also influence auditor-client alignment and might need to be controlled for. We tested the association between firms' pool type and client size (total assets), profitability and complexity (using two measures, inventory plus receivables divided by total assets and number of subsidiaries). The results are shown in Table 6. None are significant. We also estimated a logistic regression model, with firm pool type as the dependent variable, and client failure (within five years) and size, profitability and complexity as explanatory variables. Client failure is significantly $(\mathrm{p}=.023)$ and positively related to audit firm pool choice, but none of the other variables have significant coefficients. This supports the proposition that risky clients are associated with large-pool firms, even when other factors are controlled for.

\section{[Insert Table 6 about here]}

\section{DISCUSSION AND CONCLUSION}

The limitations of this study are as follows: subsequent failure of a client is a proxy measure for a risky client in a portfolio. It may be the case that clients failed which did not appear to be risky to partners in the audit firm, in circumstances which may have been difficult to foresee, or that a firm accepted apparently risky clients which did not subsequently fail. However the significant results suggest that incorrect 
risk assessments did not have a substantial effect. In addition, the sensitivity tests provide evidence that the large-pool firms accepted more risky clients when measured ex ante as well as ex post. A further limitation is that the study applies only to the publicly-listed clients of the firms, and does not provide a complete representation of the client portfolios, which may have been more or less risky than appears from examining the listed clients. ${ }^{[3]}$ Our data about partner income sharing cover the period from 1985 to 1994 . After 1994, more of the large partnerships adopted national profit pools and income allocation models based on revenues from all offices, so the distinctions between local profit pools and financially-integrated partnerships in the largest firms may have been lost in the late 1990s. Issues for future research include the reasons why certain firms choose wider or narrower pools, and the circumstances in which they change.

The results have implications for research and policy in other areas. For example, competition among audit firms may be even less than it appears to be, if a particular high-risk or low-risk client will only be considered by those firms with room in their client portfolios for it. Audit firm tenure and switching might also be subject to similar limitations, especially if a client is so risky that only large-pool firms will be prepared to take it on. The study also shows a link between partner remuneration and risk taking by audit firms. If more firms now have large-pool structures, then that would be consistent with the firms taking greater risk.

\footnotetext{
[3] We did not include unlisted companies because they do not publish their financial statements. However, we obtained some information from a published list of major companies the Management magazine Top 200 listing in 1989 and in many cases identified their auditors from a business directory (The New Zealand Business Who's Who). We observe that some firms do have different market shares in the unlisted company market. In particular, Price Waterhouse has a large share of this market, mainly consisting of subsidiaries of overseas companies. It is possible that this firm was able to assume a larger share of risky listed clients because its portfolio is balanced by lower risk unlisted clients. The information necessary to establish or disprove this is not available.
} 
This paper examines the client portfolio of Big 8 firms in New Zealand from 1985 to 1994. It tests the riskiness of Big 8 firms' client portfolios through investigating subsequent client company failure. This paper adds to our understanding of the significance of organizational characteristics of large firms by providing evidence that there were significant differences between Big 8 in terms of both client portfolio management and profit-sharing arrangements. Big 8 firms are not as homogeneous as assumed in other studies in this topic area. The results also demonstrate the correlation between the profit pool characteristics and the client portfolio of Big 8 firms. The large-pool (financially-integrated) firms are associated with more risky client portfolios, while the small-pool (financially-independent) firms adopted a more conservative approach in client portfolio management. These findings have implications for research and policy in other areas such as switching among audit firms, audit firm tenure and competition among audit firms. In many cases the choice of auditors available to a particular client may be even less than it appears to be. 


\section{Acknowledgments}

We appreciate helpful comments by Andrew Ferguson, Debra Jeter, Dan Simunic, Jenny Stewart, Jilnaught Wong and participants at the Accounting and Finance Association of Australia and New Zealand conference, Melbourne, the Audit Research Forum held by the Australian National Centre for Audit and Assurance Research at Australian National University, Canberra, Australian Capital Territory and the International Symposium on Audit Research, Sydney, New South Wales. Colleagues at the University of Auckland and Victoria University of Wellington, and William Maguire from the Manukau Institute of Technology, also provided support and ideas during the development of this study. Acknowledgment is also due to the chartered accountants who gave their time to the interview stage of the project.

\section{REFERENCES}

Baskerville R. F., and J. Beechey. 2004. An application of Adams' Theory of (In)equity to partnership income allocation. Paper presented at the Accounting and Finance Association of Australia and New zealand Conference, Alice Springs, Australia.

Burrows, G., and C. Black. 1998. Profit sharing in Australian Big 6 accounting firms: an exploratory study. Accounting, Organizations, and Society 23 (5/6), 517-530.

Carcello, J. V., D. R. Hermanson, and H. F. Huss. 2000. Going-Convert Opinions: The Effects of Partner Compensation Plans and Client Size. Auditing: A Journal of Practice and Theory 19 (1): 67-78.

Choi, J.-H., R. Doogar, and A. R. Ganguly. 2004. The riskiness of large audit firm client portfolios and changes in audit liability regimes: Evidence from the US audit market. Contemporary Accounting Research 21 (4): 747-786.

DeFond, M. 2004. Discussion of the riskiness of large audit firm client portfolios and changes in audit liability regimes: Evidence from the US audit market. Contemporary Accounting Research 21 (4): 787-794.

Francis, J. 2004. What do we know about audit quality? British Accounting Review 36: $345-368$.

Ferguson, A., J. Francis, and D. Stokes. 2003. The Effects of Firm-Wide and OfficeLevel Industry Expertise on Audit Pricing. The Accounting Review 78 (2): 429448.

Fisher, C. 2000. Who'd be an Auditor? Chartered Accountants Journal of New Zealand 79 (August) 39-40.

Francis, J., and J. Krishnan. 2002. Evidence on the Auditor Risk-Management Strategies before and after the Private Securities Litigation Reform Act of 1995. Asia-Pacific Journal of Accounting and Economics 9 (2): 135-157.

Hay, D., and D. Davis. 2004. The voluntary choice of an auditor of any level of quality. Auditing: A Journal of Practice and Theory, 23 (2) 37-54.

Holmes, S., and I. Zimmer. 1998. The structure of profit sharing schemes in accounting partnerships. Accounting \& Finance 38 (1): 51-70. 
Jones F. L., and K. Raghunandan. 1998. Client risk and recent changes in the market for audit services. Journal of Accounting and Public Policy 17: 169-181.

Krishnan, J., and J. Krishnan. 1997. Litigation Risk and Auditor Resignations. The Accounting Review 72 (4): 539-560.

Liu, X., and D. Simunic. 2005. Profit Sharing in an Auditing Oligopoly. The Accounting Review 80 (2): 677-692.

Pacini, C., W. Hillison, R. Alagiah and S. Gunz. 2002. Commonwealth Convergence Toward a Narrower Scope of Auditor Liability to Third Parties for Negligent Misstatements. Abacus 38 (October): 425-464.

Trompeter, G.., 1994. The Effect of Partner Compensation Schemes and Generally Accepted Accounting Principles on Audit Partner Judgment. Auditing: A Journal of Practice and Theory 13(2): 56-68. 
Table 1: Profit sharing in large New Zealand accounting firms, 1985-1994

(Baskerville and Beechey, 2004)

\begin{tabular}{cc}
\hline Firm & Profit sharing \\
Arthur Young** & National pool \\
Ernst \& Young* & National pool \\
Coopers \& Lybrand & National pool \\
Touche Ross** & Metropolitan pool \\
Ernst \& Whinney** & Local pool \\
Deloitte Haskins Sells** & Local pool \\
Deloitte Touche Tohmatsu* & Local pool \\
KPMG/Peat Marwick & Local pool \\
Price Waterhouse & Arthur Andersen
\end{tabular}

Note: “*” refers to merged firms after 1989, while “**” refers to the original merging firms before 1989. 
Table 2: Audit fees from clients subsequently going into bankruptcy within five

years

\begin{tabular}{ccccccccccc}
\hline Year & $\begin{array}{c}\text { Arthur } \\
\text { Andersen } \\
\text { (large } \\
\text { pool) }\end{array}$ & $\begin{array}{c}\text { Arthur } \\
\text { Young } \\
\text { (large } \\
\text { pool) }\end{array}$ & $\begin{array}{c}\text { Coopers } \\
\text { Lybrand } \\
\text { (large } \\
\text { pool) }\end{array}$ & $\begin{array}{c}\text { Deloitte } \\
\text { Haskins } \\
\text { \& Sells } \\
\text { (small } \\
\text { pool) }\end{array}$ & $\begin{array}{c}\text { Deloitte } \\
\text { Touche } \\
\text { Tohmatsu } \\
\text { (small } \\
\text { pool) }\end{array}$ & $\begin{array}{c}\text { Ernst \& } \\
\text { Whinney } \\
\text { (small } \\
\text { pool) }\end{array}$ & $\begin{array}{c}\text { Ernst } \\
\& \\
\text { Young } \\
\text { (large } \\
\text { pool) }\end{array}$ & $\begin{array}{c}\text { KPMG } \\
\text { Peat } \\
\text { Marwick } \\
\text { (small } \\
\text { pool) }\end{array}$ & $\begin{array}{c}\text { Price } \\
\text { Waterhouse } \\
\text { (large pool) }\end{array}$ & $\begin{array}{c}\text { Touche } \\
\text { Ross } \\
\text { (large } \\
\text { pool) }\end{array}$ \\
\hline 1985 & & & & & & & & & \\
1986 & & $1.35 \%$ & $9.42 \%$ & $2.62 \%$ & & $0.16 \%$ & & $1.74 \%$ & $3.92 \%$ & $7.09 \%$ \\
1987 & & $6.38 \%$ & $16.10 \%$ & $8.92 \%$ & & $2.51 \%$ & & $3.64 \%$ & $1.43 \%$ & $12.50 \%$ \\
1988 & & $6.99 \%$ & $27.86 \%$ & $16.79 \%$ & & $3.10 \%$ & & $4.73 \%$ & $5.01 \%$ & $8.62 \%$ \\
1989 & & $25.35 \%$ & $5.37 \%$ & & $2.74 \%$ & & $3.89 \%$ & $9.83 \%$ & $34.88 \%$ \\
1990 & & $6.22 \%$ & $27.37 \%$ & $5.62 \%$ & & $4.36 \%$ & & $2.53 \%$ & $3.23 \%$ & $10.96 \%$ \\
1991 & & & $0.66 \%$ & & $3.91 \%$ & & $11.94 \%$ & $3.17 \%$ & $4.24 \%$ & \\
1992 & $0.00 \%$ & & $0.22 \%$ & & $1.04 \%$ & & $6.09 \%$ & $0.00 \%$ & $27.19 \%$ & \\
1993 & $0.00 \%$ & & $0.00 \%$ & & $0.00 \%$ & $0.00 \%$ & $72.24 \%$ & \\
1994 & $0.00 \%$ & & $0.00 \%$ & & $0.00 \%$ & & $0.00 \%$ & $0.00 \%$ & $39.83 \%$ & \\
\hline Grand & & & $0.00 \%$ & & $1.62 \%$ & & $0.00 \%$ & $0.00 \%$ & $3.92 \%$ & \\
Total & $0.00 \%$ & $6.30 \%$ & $11.89 \%$ & $7.70 \%$ & $1.50 \%$ & $2.84 \%$ & $4.03 \%$ & $2.23 \%$ & $1.43 \%$ & $14.94 \%$ \\
\hline
\end{tabular}


Table 3: Client portfolios of audit firms classified by profit-sharing pool used by firm and client bankruptcy within subsequent five years

\begin{tabular}{|c|c|c|c|c|c|c|c|}
\hline \multicolumn{5}{|c|}{ Large pool } & \multicolumn{3}{|c|}{ Small pool } \\
\hline \multirow[t]{2}{*}{ Year } & Non-bankrupt & Bankrupt & Total & $\%$ & Non-bankrupt & Bankrupt & \\
\hline & $\begin{array}{c}\text { Fees in \$ } \\
\text { no. of clients }\end{array}$ & $\begin{array}{c}\text { Fees in \$ } \\
\text { no. of clients }\end{array}$ & $\begin{array}{c}\text { Fees in } \$ \\
\text { no. of clients }\end{array}$ & $\%$ & $\begin{array}{c}\text { Fees in } \$ \\
\text { no. of clients }\end{array}$ & $\begin{array}{c}\text { Fees in } \$ \\
\text { no. of clients }\end{array}$ & $\begin{array}{r}\text { Fees it } \\
\text { no. of } \mathrm{cl} \\
\end{array}$ \\
\hline \multirow[t]{2}{*}{1985} & $7,803,103$ & 422,839 & $8,225,942$ & $5.14 \%$ & $12,570,882$ & 226,259 & 12,79 \\
\hline & 81 & 13 & 94 & & 93 & 10 & \\
\hline \multirow[t]{2}{*}{1986} & $8,002,153$ & 909,542 & $8,911,695$ & $10.21 \%$ & $13,947,277$ & 696,112 & 14,6 \\
\hline & 78 & 23 & 101 & & 82 & 20 & \\
\hline \multirow[t]{2}{*}{1987} & $12,257,231$ & $2,507,911$ & $14,765,142$ & $16.99 \%$ & $17,085,472$ & $1,233,251$ & 18,31 \\
\hline & 92 & 34 & 126 & & 83 & 26 & \\
\hline \multirow[t]{2}{*}{1988} & $14,611,360$ & $3,307,457$ & $17,918,817$ & $18.46 \%$ & $19,049,170$ & 798,511 & 19,8 \\
\hline & 81 & 26 & 107 & & 62 & 18 & \\
\hline \multirow[t]{2}{*}{1989} & $15,780,960$ & $2,818,033$ & $18,598,993$ & $15.15 \%$ & $19,183,638$ & 668,337 & 19,85 \\
\hline & 54 & 18 & 72 & & 59 & 18 & \\
\hline \multirow[t]{2}{*}{1990} & $14,441,630$ & 900,808 & $15,342,438$ & $5.87 \%$ & $17,831,631$ & 622,698 & 18,45 \\
\hline & 53 & 12 & 65 & & 46 & 6 & \\
\hline \multirow[t]{2}{*}{1991} & $13,167,696$ & 462,000 & $13,629,696$ & $3.39 \%$ & $14,254,934$ & 40,010 & 14,29 \\
\hline & 49 & 3 & 52 & & 38 & 1 & \\
\hline \multirow[t]{2}{*}{1992} & $11,979,572$ & 482,000 & $12,461,572$ & $3.87 \%$ & $12,752,764$ & - & 12,75 \\
\hline & 46 & 2 & 48 & & 37 & - & \\
\hline \multirow[t]{2}{*}{1993} & $10,098,710$ & 285,000 & $10,383,710$ & $2.74 \%$ & $11,291,386$ & - & 11,29 \\
\hline & 46 & 2 & 48 & & 38 & - & \\
\hline \multirow[t]{2}{*}{1994} & $11,562,307$ & 292,730 & $11,855,037$ & $2.47 \%$ & $12,294,617$ & 75,000 & 12,36 \\
\hline & 50 & 2 & 52 & & 42 & 1 & \\
\hline \multirow[t]{2}{*}{ Total } & $119,704,722$ & $12,388,320$ & $132,093,042$ & $9.38 \%$ & $150,261,770$ & $4,360,178$ & 154,62 \\
\hline & 625 & 135 & 760 & & 576 & 100 & \\
\hline
\end{tabular}


Table 4: Tests of the significance of the differences in client portfolios between large-pool and small-pool audit firms.

Panel A: Tests of the number of risky clients

\begin{tabular}{lrrr}
\hline & $\begin{array}{c}\text { Non-bankrupt clients (in } \\
\text { five years after audit) }\end{array}$ & $\begin{array}{c}\text { Bankrupt clients } \\
\text { five years after audit) }\end{array}$ & Total \\
\hline Large-pool firms & 624 & 140 & 764 \\
Small-pool firms & 556 & 93 & 649 \\
Total & 1,180 & 233 & 1,413 \\
$\chi^{2}$ test & & & 4.067 \\
Significance & & & .044 \\
\hline & Non-bankrupt clients \\
(until 2002) & Bankrupt clients \\
& 612 & 152 & Total \\
\hline Large-pool firms & 545 & 104 & 764 \\
Small-pool firms & 1,157 & $2002)$ & 649 \\
Total & & & 1,413 \\
$\chi^{2}$ test & & & 3.544 \\
Significance & & .060 \\
\hline
\end{tabular}

Panel B: Tests of the mean percentage of fees from risky clients

\begin{tabular}{lrrrr}
\hline & $\begin{array}{r}\text { Large-pool } \\
\text { firms }\end{array}$ & $\begin{array}{r}\text { Small-pool } \\
\text { firms }\end{array}$ & $\begin{array}{c}\text { t-test for } \\
\text { difference }\end{array}$ & Sig. \\
\hline $\begin{array}{l}\text { Mean percentage in portfolio each } \\
\text { year of fees from clients failing }\end{array}$ & $11.06 \%$ & $3.26 \%$ & 3.078 & .004 \\
$\begin{array}{l}\text { within 5 years } \\
\text { Mean percentage in portfolio each }\end{array}$ & $11.63 \%$ & $3.46 \%$ & 3.229 & .002 \\
$\begin{array}{l}\text { year of fees from clients failing } \\
\text { before 2002 }\end{array}$ & & & & \\
$\begin{array}{l}\text { Mean percentage in portfolio each } \\
\text { year of fees from clients failing }\end{array}$ & $5.07 \%$ & $2.22 \%$ & 1.85 & .069 \\
within 2 years & & & & \\
Number of observations & 37 & 25 & & \\
\hline
\end{tabular}


Table 5: Client risk: financial distress measures classified by audit firm profit-sharing pool

\begin{tabular}{|c|c|c|c|c|}
\hline & Large pool & Small pool & t-test & sig. (1-tailed) \\
\hline & 757 & 632 & & \\
\hline Altman's Z score ${ }^{[4]}$ & 4.754 & 9.051 & -2.559 & 0.005 \\
\hline Zmijewski’s distress score ${ }^{[5]}$ & -1.800 & -1.931 & 1.191 & 0.117 \\
\hline $\begin{array}{l}\text { Altman's Z score weighted by audit } \\
\text { fees }\end{array}$ & 315,834 & 429,653 & -2.263 & 0.012 \\
\hline $\begin{array}{l}\text { Zmijewski's distress score weighted } \\
\text { by audit fees }\end{array}$ & $-211,989$ & $-305,665$ & 2.086 & 0.019 \\
\hline Current ratio & 4.151 & 3.506 & 0.769 & 0.221 \\
\hline Quick ratio & 3.631 & 3.084 & 0.649 & 0.258 \\
\hline Net profit margin to sales & 0.223 & -0.157 & 1.147 & 0.126 \\
\hline ROA (EBIT to assets) & 0.056 & 0.050 & 0.438 & 0.331 \\
\hline Receivables to assets & 0.147 & 0.157 & -1.265 & 0.103 \\
\hline Sales to assets & 1.139 & 0.990 & 2.288 & 0.011 \\
\hline Liabilities to assets & 0.490 & 0.462 & 1.790 & 0.037 \\
\hline Sales & $9,791,013$ & $8,837,670$ & -0.338 & 0.738 \\
\hline Assets & $339,504,556$ & $500,379,895$ & 1.701 & 0.089 \\
\hline Market capitalization & $149,716,422$ & $181,650,058$ & 0.921 & 0.357 \\
\hline $\begin{array}{l}\text { Inventory and receivables as a } \\
\text { percentage of total assets }\end{array}$ & 0.299 & 0.281 & -1.354 & 0.176 \\
\hline Number of subsidiaries & 5.47 & 5.51 & 0.090 & 0.928 \\
\hline High-risk industries ${ }^{[6]}$ & .44 & .41 & -1.351 & 0.177 \\
\hline Number of observations & 757 & 632 & & \\
\hline
\end{tabular}

${ }^{[4]}$ Altman's Z-score equals 1.2 (Current assets minus Current liabilities) +1.4 (Retained earnings/Total assets $)+3.3$ (EBIT/Total assets) +0.6 (Equity/Total liabilities). A lower score represents greater risk of bankruptcy

${ }^{[5]}$ Zmijewski's distress score equals $-4.336-4.512$ (EBIT/Total assets) +5.679 (Total liabilities/total assets) +0.0004 (Current ratio). A higher score represents greater risk of bankruptcy.

${ }^{[6]}$ High-risk industries are property, investment, mining, tourism, high technology and biological. 
Table 6: Logistic regression of audit firm pool, risk and control variables

Large-Pool $(0,1)=a+b 1($ FAILED5) + b2Ln(ASSETS $)+b 3($ ROA $)+b 4($ INVREC) + $\mathrm{b} 5($ SQSUBS $)+b 6(\mathrm{CA} / \mathrm{CL})+\mathrm{b} 7(\mathrm{TD} / \mathrm{TA})+\mathrm{b} 8($ LISTED $)+\mathrm{e}$

\begin{tabular}{|c|c|c|}
\hline Independent Variable & Coefficient & p-value \\
\hline FAILED5 & .355 & .023 \\
\hline Ln(ASSETS) & -.044 & .227 \\
\hline ROA & .003 & .993 \\
\hline INVREC & .381 & .128 \\
\hline SQSUBS & .053 & .243 \\
\hline Constant & .686 & .284 \\
\hline Model Chi-square & 10.993 & .052 \\
\hline $\begin{array}{l}\text { Overall correct classification } \\
\text { percentage }\end{array}$ & $56.0 \%$ & \\
\hline Cox \& Snell $\mathrm{R}^{2}$ & .009 & \\
\hline Nagelkerke $\mathrm{R}^{2}$ & .012 & \\
\hline Number of observations & 1,413 & \\
\hline
\end{tabular}

Large-Pool: companies with large-pool auditors (1) others (0); FAILED5: companies going into bankruptcy within 5 years; Ln(ASSETS): natural log of total assets; ROA: ratio of EBIT to total assets; INVREC: ratio of inventory and receivables to total assets; SQSUBS: square root of the number of subsidiaries. 